\title{
Social and Environmental Drivers of Climate Change Vulnerability in the Niger Delta region, Nigeria
}

\author{
B. Authority
}

\section{ABSTRACT}

Studies have revealed that the Niger Delta region of Nigeria is only three meter above mean sea level and their coastline is dynamic in nature which renders hundreds of coastal communities exposed and vulnerable to climate change risk and hazards. The region is faced with seasonal flooding, increase in temperature, high precipitation, erosion, river salinization, ocean surges and siltation. In this paper, we reviewed over 80 publications on related subjects of social, economic and environmental drivers of climate change vulnerability in the Niger Delta and their recurring and predicted impacts. Lack of empirical baseline data on climate change, inadequate enforcement of environmental laws, insignificant state fiscal budget on climate change, lack of political will and low interest of political leadership, absence of state policies aimed to enhance climate change adaptation and mitigation, persistent cases of oil spills and gas flaring by multinational oil companies, low public awareness and inadequate technical capacity were identified and analyzed as multidimensional factors militating against local effort for climate change adaptation and mitigation in the Niger Delta region. The state governments, multinational oil companies, intervention agencies, research institutions and critical community stakeholders especially in coastal areas in the Niger Delta should work together to achieve a systematic integrated plan for long term risk prevention and impact reduction through adaptation and mitigation approaches. Furthermore, strategic local solutions should include the assessment of impacts of climate change on social, environmental, and economic sector at the state, local government and community level. This should be accompanied with smart green policy measures and implementation of elaborate regional climate change education programs, development of skill sets for green entrepreneurship among youths and established framework of sustainable economic development in the region.

Keywords: Climate, Drivers, Environment, Social.

\section{INTRODUCTION}

The Intergovernmental Panel on Climate Change - IPCC defined climate change as a change in climate that is directly or indirectly cause by human activities which negatively altars the natural composition and functioning of the atmosphere and combine with natural climatic variability were observed over a long period of time [1]. Coastal lands in Africa are becloud by environmental challenges associated with climate change related disasters such as flooding, erosion, acid rain, extreme precipitation, high temperature, sea level rise and increase in pest and diseases[2]-[5]. The Niger Delta is three meter above mean sea level on sandy barrier islands bordering the sea shores and the region could lose over $15000 \mathrm{~km}^{2}$ to land with one meter rise in sea level by 2100 [6]. The results of assessment
Published Online: October 12,2020

ISSN: $2684-446 \mathrm{X}$

DOI :10.24018/ejgeo.2020.1.5.69

B. Authority *

Niger Delta University, Nigeria. (e-mail: authorityben@yahoo.com)

*Corresponding Author of vulnerability of coastal communities to sea level rise in the Niger Delta indicates that the coastline is dynamic in nature which renders communities dwelling in proximity to the shore exposed and vulnerable to ocean surges and erosions exacerbated by sea level rise [7]. The vulnerability of coastal communities to climate change in the region can be analyzed in relation to induced natural and anthropogenic causes such as modification of river flow due to construction of jetties, dams, channelization and mining of mineral resources (oil, sand, gravel and gas) and as well as urban sprawl on flood planes. Hence, increase in frequency and duration of flood in the region over time has affected its basin hydrology, stream morphology and shoreline dynamics causing wave erosion, salinization of rivers and modification of fragile ecosystems [8]. 
There is paucity of scholarly publications on vulnerability and adaptation of Niger Delta coastal settlements to sea level rise; and its social, physical, and economic vulnerability to climate change [9]. Nonetheless, some authors asserts that many state capital cities in the region including Port Harcourt, Oyo, Yenagoa, Asaba and Warri are worst hit by climate change due to its geographical locations, increase in population of urban poverty, settlement on low lands such as swamps and marshy lands, use of substandard building materials that cannot stand environmental stresses, environmental degradation and lack of government commitments to managing climate related disasters [10]. Nigeria is experiencing persistent off-season rainfall due to climate change, and about $75 \%$ of Niger Delta land may lose if sea level rises to 1 miter as large proportion of mangrove forest i.e. buffer zones have been destroyed by oil spills and about 12 million Metric Tones (MT) of $\mathrm{CH}_{4}$ is being discharged to the environment yearly by gas flaring from multinational oil companies [11]. Moreover, half of the 15 million people in Lagos state leave less than six feet above sea level and the Sahara desert in northern part of Nigeria is advancing at 600 meters per year and destabilized over 10 states including Jigawa, Bauchi, Adamawa, Kadana, Kano, Niger and Nasarawa state etc.[12].Also, climate change has been linked to exacerbating diseases such as Pneumonia, Cholera, Psychological Stress, Asthma and Malaria due to water contamination, and spread in disease carrying vectors [13].

The IPCC defined adaptation as an adjustment of human or natural systems or condition in response to changes in the environment aimed to prevent and moderate harm and explore opportunities for sustainable development [14]. In developed countries the impact of climate change is less severe due to high adaptation techniques, mechanized agriculture, direct funding, high awareness, advance research, political commitment and law enforcement [15]. The need for climate change adaptation in the Niger Delta is critical, logical and explicit in relation to community exposures to hazards and disasters due to natural and anthropogenic causes of vulnerability. This paper examined specific social and environmental factors driving exposure, risk, and vulnerability of people in the Niger Delta to climate change related disasters, and the biophysical and social dynamic impacts. The paper further analyzed current challenges that could limit effective adaptation approaches, surveyed theoretical background and previous research on earlier proposed adaptation and mitigation measures, and made policy recommendations for effective climate change resilience strategies as prerequisite to sustainable development in the Niger Delta region.

\section{GEOGRAPHY Of THE STUDY AREA}

Nigeria is a country in West Africa that covers an area of $923,773 \mathrm{~km}^{2}$ having an estimated population of over 170 million people [16]. The focus of this study is the Niger Delta region situated at the top of the gulf of Guinea with a land mass of $7.5 \%$ and makes up about $12 \%$ of Nigeria surface area $\left(112,000 \mathrm{~km}^{2}\right)$ with an estimated population of
31 million people in about 3000 communities [17], [18]. Equally, the Nigeria coastline of $853 \mathrm{~km}$ is crisscrossed by extensive estuaries that form the Niger Delta swamp in the middle where the region flood plain drains Niger and Benue rivers that extends $450 \mathrm{~km}$ in the West to the Imo River in the East and drains to the Atlantic Ocean in the south- south states in the Niger Delta including Cross River, Akwa Ibom, Delta, Rivers, Edo and Bayelsa state (Fig. 1) [19]. About $97 \%$ of the Nigeria economy is dependent on oil and gas explored from the Niger Delta consisting of 9 oil producing states (Bayelsa, Rivers, Edo, Delta, Akwa-Ibom, Imo, Ondo, Abia and Cross river state) and there are over 900 active oil wells in the region and since the commencement of oil production there has been incidents of massive oil spill, and other severe widespread oil and gas related environmental pollution activities [20].

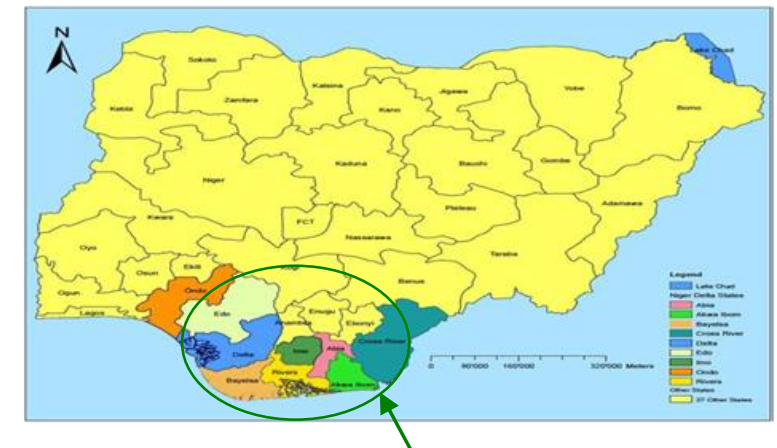

Fig. 1. Map of Nigeria showing oil producing states in Niger Delta Region (excluding offshore production beyond the lower limit of the continental shelf) [21].

In 2008 about 2000 sites was contaminated by oil exploration activities in the Niger Delta and this destroyed mangrove forests, farmlands, wetlands and renders folks in oil producing communities vulnerable to life threatening diseases such as cancer, genetic mutation, birth defect, cardiovascular diseases and asthma) [22]. Oil and gas fields are located both offshore and onshore where oil pipelines crisscross communities and farmlands in places such as the Ogoni land, Imiringi, Oso, Bonga, Ubit, Bomu and Assan etc [23], [24]. Some authors who carried out studies on the Kyoto protocol and carbon footprint of nations, some key drivers of climate change vulnerability are social, infrastructural, economic, cultural, environmental and institutional characteristics underlying development in time and space [25].

\section{Social Drivers OF Climate CHANGe In THE NigeR DELTA REGION}

Climate change vulnerability refers to the degree of susceptibility of an area or location to the hazards of climate change, such susceptibility is determine by the characters, magnitude and rate of variation to which a system is exposed to, sensitive to and its adaptive capacity [26]. The vulnerability of human, socioeconomic, biological and geographical system in a region is exacerbated by natural and anthropogenic factors. At the centers of anthropogenic factors are human whose action or inaction contribute to 
vulnerability, these include building social infrastructures, agriculture activities and industrial productions [27]. Some authors argued that the social dimensions of climate change are under-studied at the local level and consideration of social drivers of climate change vulnerability in climate policy is a precondition to ensuring that the rights of vulnerable people are respected as climate change impairs social security, livelihoods and health [28], [29], [31]. Also, a successful adaptation and mitigation approach depends on identification of drivers of vulnerability, sheared knowledge among affected population and collective response through policy and practice [31]. The following social and environment factors were identified, critically analyzed, and discussed as drivers of climate change vulnerability in the Niger Delta with measurable impacts.

\section{A. Lack of Awareness}

A study conducted by some authors on climate change awareness and adaptation in Delta, Rivers and Cross river state in the Niger Delta region with 400 participants including farmers, civil servants, business owners and students using multi-stage sampling techniques shows that $60 \%$ of participants know nothing or little about the causes and impacts of climate change [32]. In a related study carried out in 2015 on public perception of climate change in Bayelsa state capital with 360 participants the results shows that $43.33 \%$ lack knowledge about climate change, $48.7 \%$ believed that one of the natural causes of climate change is divine providence and over 55\% are not aware that carbon dioxide $\left(\mathrm{CO}_{2}\right)$ is the major greenhouse gas contributing about $55 \%$ to global warming. The author also revealed that the major sources of information on climate change as indicated by participants were television, personal experience and radio program [33]. Despite the region is volatile and prone to environmental hazards, there is low public awareness on the danger of climate change disasters and government response to climate change incidence are often poorly planned and tokenistic especially when climate change related disasters such as severe flooding, massive erosion and water pollution occurs [34].

Public awareness in climate change is important to the people of Niger Delta for the purpose of anticipatory climate change adaptation which is a process of proactively taking actions in preparation to halt or minimize the adverse impacts of climate change [35]. The low awareness of climate change in the region may be due to inadequate sources of information and programs, absence of geography and environmental subjects in primary and secondary school curriculum and lack of sensitization at community level. However, adequate knowledge on natural and anthropogenic causes of climate change and their socioeconomic and health effects among the population is vital in order to have a regional population that is aware of, and concerned about the environment and its associated problems. Awareness is also a vital ingredient of knowledge, skills, attitudes, motivations, and commitment to work individually and collectively towards proffering solution to climate change problems and prevent new ones.

\section{B. Population Growth}

The Nigeria National Population Commission (NPC) census returns in 2006 shows that the population of Niger Delta is 31.2 million people distributed within the nine states (Table 1) [36]. According to Gideon who cited the work of Centre for Population and Environment Development between 2010 and 2015 the population of the region was about 33.8 and 39.2 million respectively, and by 2020 it was estimated at $45.7 \%$ [37].

Out of the 9 states rivers state has the highest population, followed by Delta, Akwa Ibom and Imo state with a population above three million people. Generally, based on 1991 population census, the overall population density per person in the Niger Delta was 182 square kilometer [38]. The pattern of settlement in the region is determined by drainage and topographic landscape, there is small dry land in narrow strips in the coastal beach ridge areas, and people prefer to settle on high land due to low land surface areas characterized by estuaries, creeks and swamps. Some densely populated areas of settlement are Nembe, Burutu, Warri, Bonny and Akassa. Additionally, areas that have sparely distributed settlements are due to limited high dry lands in isolated areas and their predominant fishing occupation along river basins.

TABLE 1: STATES AND THEIR CAPITAL AND LAND SIZES IN THE NIGER DELTA

\begin{tabular}{cccc}
\hline $\begin{array}{c}\text { States in } \\
\text { Niger Delta } \\
\text { region }\end{array}$ & Land Area & Population [36] & Capital City \\
\hline Bayelsa & 11,007 & $1,703,358$ & Yenegoa \\
Rivers & 10,378 & $5,185,420$ & Port \\
Cross River & Cross River & 21,930 & Calabar \\
Akwa Ibom & 6,806 & $3,920,208$ & Uyo \\
Delta & 17,163 & $4,098,391$ & Asaba \\
Edo & 19,698 & $3,218,332$ & Benin City \\
Ondo & 15,086 & $3,441,014$ & Akure \\
Abia & 4,877 & $2,833,999$ & Umuahia \\
Imo & 5,165 & $3,934,899$ & Owerri \\
Total & $\mathbf{1 1 2 , 1 1 0}$ & $\mathbf{3 1 , 2 2 4 , 5 8 7}$ & N/A \\
\hline
\end{tabular}

Although increase in population growth in Nigeria is often regarded as political advantage in some part of the country, it is parallel to increase in energy consumption, carbon emissions, carbon foot print and air pollution. For instance, population boom in the region has exacerbates automobiles and diesel fired electricity generators contributing to choking smog in the atmosphere in cities like Port Harcourt, Asaba, Bennin and Calabar [39]. Increase population has equally results to high demand in fossil fuel resulting to more air pollution and carbon emission and the establishment of all kinds of industries that has changed natural landscapes and negatively impacts ecosystems [40]. In addition, population increase in the Niger Delta is associated with increase in water consumption, urban sprawling and blight, increased poverty and waste generation.

Some authors asserts that population growth is a key factor to the negative modification of Nigeria's environment as the growth and size of human population are well 
established as major drivers of environmental change, including carbon emission [41], [42]. However, the complex environmental effects of demographic shift and population growth is poorly researched and documented in Nigeria including the Niger Delta. The unchecked exponential population growth in the Niger Delta may render larger population vulnerable to climate change especially the poor whose livelihood depends on the environment. This may increase the cost of climate change mitigation and undermined government effort for adaptation programs.

\section{Poverty}

There is need to analyze how the poor are vulnerable to climate changed induced natural disaster such as flood and desertification and how other environmental factors like polluted drinking water, contaminated air and lack of environmental sanitation affect the poor. The effects of climate change is anticipated to severely affect those living in poverty the most, due to their common dependency on the very natural resources impaired by climate change and their less capacity to quickly adapt and protect themselves[44]. This situation is observable in the Niger Delta as poor people who harvest natural resources from the ecosystem for livelihood are becoming poorer due to dwindling water resources, low agricultural yield and increase in air born diseases and displacement by floods and erosion [45].

A report of the United Nations Conference on Sustainable Develop also known as the Rio Earth Submit held in Rio de Janeiro in 2012 identify poverty as the greatest challenge facing the world today and woo international commitment to eradicate poverty as indispensable requirement for sustainable development [46]. Scholars have established a positive correlation between poverty and pressure on biomass energy for cooking amongst the six geopolitical zones in Nigeria and people in the Niger Delta tend to use more fuel wood for cooking, therefore, large population in the rural areas are involved in deforestation which is escalating climate change vulnerability and its related disasters in the area [47].

Most large households in the Niger Delta region lack purchasing power for cooking gas or electric cooker and resort to harvesting fuel wood from the forest. The practice of deforestation causes the loss of biodiversity and removes soil cover which results to carbon emission and exacerbate climate change. In an effort to address poverty, governments in the region are focused on providing basic necessities and infrastructures to citizens without concerted effort to address climate change through appropriate measures such as policy formulation, investment in technology and sound agricultural practice. Poverty as a driver of social vulnerability to climate change in the Niger Delta undermines government effort in tackling climate change, distorts citizens' perception about the severity of the problem and diminished their capacity to keep off from environmental harmful practices and consequently increasing their risk to climate change vulnerability.

\section{Lack of Political Will}

By political will we refer to deliberate involvement, commitments and participation of political office holders in the Niger Delta aimed to building climate change resilient communities through policy formulation and implementation, funding, investment, advocacy, capacity building, research and information sharing. Equally, there is lack of political interest and willingness of politicians in the Niger Delta at all levels of government (ranging from legislators, executives and judiciary) to initiate and fund programs to tackle crisis posed by climate change [48], [49]. For instance, despite the glaring negative impacts of climate change on human health, social economy, agricultural sector, wetland and biodiversity in the Niger Delta as points out by other scholars government is yet to develop or create budgets aimed to fund climate change adaptation and mitigation programs[50], [51].

Unfortunately, Government Ministries of Environment in the Niger Delta are not caring out interventions on climate change adaptation and mitigation in vulnerable communities due to lack of fund, often there is no provision in state annual budgets to address environmental problems like climate change, flooding and poor waste management problems. The continuous negligence to climate shift from government may result to shortage and degradation of natural resources such as land and water which may fuel negative secondary effects such as hunger, sicknesses, displacement and increase in joblessness which may create social conflicts and civil disobedience against government. Arguably, the social, economic, scientific and political implications of climate change in the Niger Delta are still poorly understood by critical stakeholders including political and non-political decision makers at all level of government ministries, departments and agencies.

\section{ENVIRONMENTAL DRIVERS OF CliMATE CHANGE IN THE NIGER DELTA REGION}

Environmental drivers of climate change vulnerability in the Niger Delta include biodiversity lose, poor waste management, unplanned land use and gas flaring by multinational oil companies which are induced by both natural and anthropogenic factors. As it was indicated in Nigeria's first national communication to the UNFCCC in 2003 , about 15 to $35 \%$ of Niger Delta would be lose at accelerated sea level rise (ASLR) of $0.5 \mathrm{~m}$. Though the values may vary in time and space, at ASLR of $1.0 \mathrm{~m}$ about $75 \%$ of the Niger Delta would be lose [52]. Presently, the impacts of seal level rise are felt in coastal areas through the interactions of ocean currents, waves, tides and storm surges causing erosions and lose of mud houses to water.

Some scholars who conducted a study on the vulnerability of coastal communities in the Niger Delta region to sea level rise found that low lying settlements in coastal areas require vulnerability mapping against flooding and inundation sequel to sea level rise. They revealed that $25.9 \mathrm{~km} 2$ of the study area fell within 0 to 1 meter above sea level and was classified very high vulnerable area, while high vulnerable areas were delineated to represent a total of $14.58 \mathrm{~km}^{2}$ land 
area at 2 to 3 meter above sea level [53]. Essentially, rainfall and precipitation are the most important elements of climate change characteristics in the Niger Delta. The region experiences large spatial and temporal variations in rainfall than other components of weather and climate. For instance, rainfall records in Bayelsa, Delta, Rivers and Akwa Ibom state shows that the mean annual rainfall was $300 \mathrm{~mm}$ to $400 \mathrm{~mm}$ which have direct implications in seasonal flooding between Septembers to November [54].

Some anthropogenic factors inducing climate change in the Niger Delta are gas flaring by multinational oil companies, sand mining, indiscriminate waste dumping, artisanal oil refining, uncontrolled timber harvesting, degradation of reserved forests, biodiversity lose, unsustainable agricultural practices and high fuel consumption in the transport sectors.

\section{A. Biodiversity Loss}

Biodiversity resources in the region comprised of various species of fauna and flora including reptiles, amphibians, microorganisms, mosses, liverworts, gymnosperms, chlamydosperms, monocotyledons and dicotyledons plants [55]. Biodiversity provide shelters and habitats to microorganisms; serve as energy source, fibre, wood, educational materials, clothing, income, utensils, construction, medicine and ecotourism [56].

However, some researchers who assessed the diversity of terrestrial vertebrates in Taylor Creek forest reserve in the Niger Delta explained that most reserved forest in the region is highly vulnerable to excessive human pressure including urbanization, haunting, deforestation, habitat destruction, soil erosion and bush burning [57]. Some key causes of biodiversity loss in the Niger Delta include flooding, crude oil prospection and exploration, deforestation, population growth, uncontrolled bush burning and urbanization [58]. The loss of biodiversity results to the loss of its roles in reducing carbon dioxide and other sensitive gases contributing to climate change in the atmosphere. For instance, deforestation releases $\mathrm{CO}_{2}$ into the atmosphere, alter regional climate change, accelerate flooding, decrease soil fertility and exacerbate desertification [59]. The loss of biodiversity such as native fish and plant species aggravate poverty in coastal areas as people who depends on them for food and source of livelihood find it difficult to earn a living. This situation motivates affected persons in the region to deplete other types of natural resources as replacements to the loss of the species and therefore further exacerbating to climate change.

\section{B. Poor Waste Management}

The most common type of waste being generated in the Niger Delta is Municipal Solid Waste (MSW) which are needless solid materials or non-liquid substances commonly known as refuse or garbage that originate from human activities including domestic, commercial, industrial and agricultural activities [60]. Some examples of prevalent waste disposed in the region are metals, plastics, glass, organic and household waste including buckets, pots, pans, scrap cars, generators, sinks, pans, poles, refrigerators, polythene bags, used tyres, old electrical appliances, wine and chemical bottles, ceramic plates, cups and empty bottles. Nonetheless, ;/domestic waste are general household refuse which includes food items, clothes, fruits, vegetables, and damaged utensils, while commercial waste are generated from shops, restaurants, medical facilities, schools, construction activities, and auto-mechanic repairs. These wastes can be classified based on point and non-point sources, properties, degradability and toxicity [61].

A proper municipal waste management system involves several procedures which segregation, packaging, storage, transportation, processing, resource recovery, recycling and disposal [62]. A survey carried out by the health and demography department of Nigeria National Population Commission shows that only $14 \%$ of Nigerians have access to reliable household waste disposal system and $87 \%$ of the population used unsanitary disposal method of dumping waste in the bush and along the highway [63]. The volume of waste generated in the Niger Delta can be attributed to several factors including population density in a particular area, level of income and industrialization, unguided attitude and lifestyle orientation and poor legislation [64].

Waste dump along the road or in the bush (open dumping and landfill) are transported by surface runoff during rainfall into drainages, pits, streams, wells and leachates in open dumpsite that contains copper $(\mathrm{Cu}$,$) zinc (\mathrm{Zn})$, Aluminum $(\mathrm{Al})$, Iron $(\mathrm{Fe})$ and Lead $(\mathrm{Pb})$ sink down to water table and contaminate underground water and consequently pose public health risks [65], [66]. Also, there are established evidence of underground water contamination and pollution by petroleum waste products from multinational oil companies operating onshore and offshore in different parts of the Niger Delta which has caused severe public health problems in oil bearing communities and also impaired ecosystems as was shown in UNEP Ogoni Environmental Impact Assessment report in 2011 [67]-[69].

Like other parts of the country, waste collection is only found in urban areas in the Niger Delta because rural areas mainly generate organic waste that degrade easily while non-biodegradable waste are burn in the open. However, open incineration of municipal solid waste of any kind pollutes the air and release greenhouse gases such as $\mathrm{CO}_{2}$, methane, nitrous oxide, and nitrogen into the atmosphere which contribute to climate change. Furthermore, anaerobic bacteria break down organic waste in open dumpsite and release methane gas and carbon dioxide $\left(\mathrm{CO}_{2}\right)$ into the atmosphere which degrade air quality and exacerbate global warming [70].

However, several factors are responsible for poor waste management in the Niger Delta region. These include lack of waste treatment plants, inadequate funding on research and local technology development, inadequate trained personnel, non-enforcement of waste management legislation, negative conflicts of interests among government agencies and limited upland areas especially in coastal states like Bayelsa, Delta and Rivers state. Nonetheless, a sustainable waste management system in the Niger Delta must strive to reverse these ugly trends and centers on 3-Rs policy (Reduce, Recycle and Reuse). 


\section{Unplanned Land Use}

The discovery of crude oil in the Niger Delta contributes to changes in land use pattern because lands that were devoted to traditional agricultural systems became oil fields and this alters the geospatial structures of arable lands. In most cases, areas that were once pristine including mangroves and swamp forests and wetlands became severely degraded by oil spills and loss their ability to sequester carbon [71]. Furthermore, the absence of land use planning and zoning in the Niger Delta coupled with government inability to initiate basic technical engineering and participatory climate change disaster resilient measures, renders communities vulnerable and increased their risk of natural disasters [72]. For instance, there is no consistent Federal and State government program designed elicit landuse change assessment and monitoring to integrate green development and ecosystem conservation.

At the heart of the problem is haphazard infrastructural development where both government agencies and individuals erect buildings on floodplains and canals thereby blocking free flow of water and exacerbating water log, flooding, erosion and environmental contamination and pollution which magnifies impacts of climate change disasters in urban areas and rural coastal communities in the region. Worst still, presently, the impacts of climate change on land use, fauna, flora, and livelihood has not been recognized by governments in the Niger Delta [73].

Some studies conducted on mainstreaming climate change into Environmental Impact Assessment (EIA) process in the Niger Delta emphasized that government at all levels in the region should mainstream climate change impact assessment in EIA procedures for the purpose of analysis, evaluation and prediction of the implications of climate change on ecosystem and social population in all proposed development projects [74]. Equally, the use of Geographical Information System (GIS) is vital to project or predict the consequences of environmental changes in relation to climate change related disasters and other critical environmental problems and aid planning for disaster preparedness [75].

\section{Gas Flaring by Multinational Oil Companies}

Gas flaring has been going on in the Niger Delta for the past 50 years (since 1956) with associated environmental and health consequences [7]. Though the Nigerian federal government has announced several deadlines to end gas flaring, and each deadline has reached, yet flaring continues unabated [77]. Studies conducted on climate change and energy implications of gas flaring for Nigeria shows that gas flared in the Niger Delta has enormous carbon dioxide, methane propane and butane exacerbating global warming [78].

It has been established that about 17.2 billion $\mathrm{m}^{3}$ of natural gas is flared annually from the Niger Delta and this has produced more emissions of greenhouse gases than all other sources in sub-Saharan Africa combined [79], [80], [81]. Worst still, most flare sites are located close to residential areas and farmlands which are causing acid rains, dwindling farm yields and public health crisis including skin irritation, eye infection, heat irritation and genetic mutation as were shown in UNEP report in Ogoni Land in 2011[82].

The results of studies carried out on assessment of gas flaring in Niger Delta in relation to cost, ecology and human health implications established that gas flaring is the primary source of anthropogenic pollutant which is responsible in producing toxic greenhouse gases and driving climate change vulnerability with corresponding risks, poor air quality, public health crisis and overall ecological degradation in the Niger Delta region. Additionally, the authors asserts that flaring and venting of natural gas in the Niger Delta contributes about 35 million metric tons yearly of carbon dioxide $(\mathrm{CO} 2)$, sulfur dioxide and methane $(\mathrm{CH} 4)$ and other forms of GHGs, and thus escalating the immediate and long term impacts of climate change vulnerability in oil and gas producing communities in the region [83].

The local environment is constantly incinerated by high temperature and heat which renders vast areas of land at flare sites uninhabitable and non-useful for agriculture due to its harmful effects on flora, fauna, soil and water as a result of acidification by pollutants emitted from flaring. However, the primary onus to end gas flaring rest entirely on Nigeria Federal government. It is achievable to end gas flaring through upgrading of relevant anti-gas flaring regulatory standards, implementation and enforcement of such laws including the Nigeria Petroleum Act of 1969 and the Associated Gas Re-injection Act No.99 of 1979 based on principles of transparency and accountability practice.

\section{Challenges To Climate Change Adaption In The Niger DELTA REGION}

\section{A. Absence of Baseline Data on Climate Change}

There is dearth baseline information in government ministries, departments and agencies (public institutions) to inform planning for anticipatory climate change adaptation strategies at state and regional level based on empirical research, information surveys, policy reviews and climate change impact assessment on prevailing conditions and projection of severity of climate change on agriculture, biodiversity, human health, water resources, energy, social economy, employment and gender in the Niger Delta.

The Inter-governmental Panel on Climate Change (IPCC) Fifth Assessment Report in 2013 indicates that key sectors affected by climate change are education, energy, fisheries, food and agriculture, forestry, health, infrastructure, nature and ecosystem conservation, spatial planning, tourism, transport, waste and water. Therefore, solution to climate change must be rooted in baseline information on how climate change has affected these key sectors in the Niger Delta so as to enable government and development agencies provide long term practical, reliable and broad stakeholders participatory measures for climate change adaptation and mitigation. Additionally, the lacks of baseline data frustrate systemic monitoring and evaluation procedures against changes cause by the effects of climate change on key sectors in the Niger Delta. This also undermines the process for selection of adaptation options for climate change and mitigation strategies and consequently fostering the vulnerability of the people and their environment. 


\section{B. Lack of Prioritize Funding on Climate Change}

Presently, there is no annual state budgetary provision to address the socio-economic and environmental challenges posed by climate change in various sectors in the State Ministry, Development and Agencies (MDA) which can help to abate the plight of communities in the region. There is also the issue of lack of fund for research in tertiary institutions and inadequate educational programs to facilitate public awareness through media channels and workshops.

Furthermore, there is lack of government initiatives and commitments towards promoting renewable energy and green transportation systems through adequate funding in the key sectors. Thus, there is need for the regional and state governments to provide and facilitate adequate funding for programs aimed to mitigate climate change through investment agricultural to promote climate change resilient crop varieties, use of environmentally friendly fertilizers, sustainable water use, soil management, tree conservation, credit and risk insurance schemes for farmers and the poor in the Niger Delta. A deliberate funding mechanism is required from government and multinational oil companies such as Shell JV, ExxonMobil JV, Nation Oil Company (NAOC), Total final Efl JV etc. that are flaring natural gases and exploring crude oil in the region.

\section{Inadequate Policy Focus on Climate Change}

There is tendency to focus on negative effects of climate change debate on the affected population rather than focusing on providing solutions. While there are intractable challenges to overcome, there are also opportunities that are beyond the immediate sphere of climate effects. A successful climate adaptation must be centered on the right policy tools that permeate all strategic ministries, departments and agencies at the state and regional institutions backed by strong political will, public awareness, stakeholders' participation and consistent action plan which are not yet available and accessible in the Niger Delta region and therefore not being integrated in social development programs. Also, many critical stakeholders are not informed of the important of government policy and roles of government agencies on climate change adaptation and mitigation measures in Niger Delta region.

Most importantly, environmental policy is expected to remedy unsatisfactory situations which affect the public and this begins with the identification of environmental problems. The process of formulation and implementation of environmental policy requires public participation that would lead to the development of proposed course of actions aimed to solve the problems. Nonetheless, the problem of climate change and its associated causes and impacts is not yet well recognized by law in the country, and not yet considered a priority in state policy development.

Furthermore, the complex nature of environmental and social drivers of climate change and their related impacts in virtually every facets of the society in the Niger Delta requires highly professional skills to provide strategic adaptation solutions. Presently, there is low expertise in both human resources and technology in strategic public institutions including regional agencies such as the Niger
Delta Development Commission (NDDC) and the Ministry of Niger Delta.

\section{POLICY RECOMMENDATIONS FOR ADAPTATION AND Mitigation of Climate CHANGE IN THE Niger DELTA}

Climate change adaptation in the Niger Delta requires holistic systematic planning, risk and impact assessment of social, environmental and economic vulnerabilities of key sectors at the state, local government and community level. Policy strategies must be centered on quality and reliable data sets on environmental aspect such as forest cover, water resources, soil, biodiversity, and socio-economic data including population dynamics, economic development forecast, urbanization trends, infrastructural development and gender and as well as climate data which include seasonal forecast, national and local weather data on precipitation and temperature and climate model projection into the future.

There is need for SMART (Specific, Measurable, Achievable, Realistic and Time bound) policy adaptation planning that involved case and field study research which analyze estimated damages to specific vulnerable areas and assets, types and nature of damages or losses and provide cost effective adaptation options, long and short term high priority issues with budgetary breakdown, clear and flexible adaptation plan where the implementation can be monitored and replicated. Furthermore, it is necessary to design and finance elaborate regional education program in ministries and development agencies including primary, secondary and tertiary institutions of learning aimed to inculcate knowledge and understanding on the reality of climate change risk, measurable impacts and available opportunities for human empowerment to adapt and effectively mitigate the impacts of climate change at community level. Equally, government and oil companies operating in the Niger Delta should provide flexible economic opportunities for youths to take advantage at all levels of human endeavor to explore and create innovate scientific and business related solutions to reducing greenhouse gas emission related activities and enhance community resilience to climate change.

It is vital to create centers at strategic location in the nine states in the Niger Delta for comprehensive skills development and training in tandem with sound environmental policies in order to create job opportunities for transition to green economies. Such training should target opportunities in renewable energy (solar and wind), waste management and recycling, inclusive environmentally friendly agricultural practice, and planting of economic trees. Furthermore, the poor and marginalized person in communities who very much depends on the natural environment should be enlightened about the severity of climate change effects on various aspects of lifestyle. Moreover, people should be allowed to choose adaptation options that are favorable to their local environment and economy. This approach will entice non-climate change optimists and humanitarian agencies to pick interests and perhaps actively play supportive roles in terms of provision of funding opportunities to environmental scientists in 
planning and implementation of socially embracing climate change adaptation and mitigation programs.

Green economic growth can be achieved in large scale in the Niger Delta region within the framework of sustainable development, while also addressing climate change; these two objectives should be seen as complementary not mutually exclusive. There is need for collaboration between states and federal government of Nigeria to create green zones and green cities to raise social awareness in coastal areas in the Niger Delta. Also, government need to invest in green energy (solar and wind power) and provide sound technology for early warning system in relation to climate change elements in vulnerable areas.

In this paper we outlined the social and environmental drivers of climate change vulnerability in the Niger Delta. We identified and analyzed the complex and multidimensional social and environmental challenges faced by efforts for social and intuitional effective adaptation and mitigation strategies. Given the lack of empirical baseline data, insignificant state budgetary funding, absence of state policies, low political will, lack of stakeholders awareness, and adequate technical capacity the prospect for quick, easy and long term social wide spread adaptation and mitigation actions seems daunting and difficult to predict.

Following reviews of literatures on factors exacerbating climate change risk in the Niger Delta region, various natural and anthropogenic activities or factors exacerbating climate change related disasters in the region where identified. These include the proximity of coastal communities to seashore, exposure to ocean surges, settlement in lowland areas, modification of river flow by construction of jetties, dam, channelization and the mining of mineral resources (sand, oil, gravel and gas), persistent flaring of natural gases by multinational oil companies, loss of blue carbon ecosystem, lack of waste management system, unsustainable agriculture practices, increased deforestation, and urban sprawling on flood plane.

In this paper we outlined the social and environmental drivers of climate change vulnerability in the Niger Delta. We identified and analyzed the complex and multidimensional social and environmental challenges faced by efforts for social and institutional effective adaptation and mitigation strategies. Given the lack of empirical baseline data, insignificant state budgetary funding, absence of state policies, low political will, lack of stakeholders' awareness, and inadequate technical capacity. Therefore, the prospect for quick, easy and long term social widespread adaptation and mitigation actions against climate change in the Niger Delta region is daunting.

\section{ACKNOWLEDGMENT}

I appreciate the support of Melford Benson, Professor Peter James Kpolovie and Dr. Endurance Zacchaeus.

\section{REFERENCES}

[1] Intergovernmental Panel on Climate Change (IPCC). Introduction, in Climate Change 2013: The Physical Science Basis, Contribution of Working Group 1 to the Fifth Assessment Report of the Intergovernmental Panel on Climate Change. 2013.

[2] N.P. Chidumeje, L. K. Okonkwo, \& T. Subhashni. (2015). The Niger Delta wetland ecosystem: What threatens it and why should we protect it? Afr. J. of Env. Sci. and Tech. 9(5). Pp. 451-463.

[3] P. Odjugo. (2005). An analysis of rainfall pattern in Nigeria. Global journal of environmental science. 4(2). Pp. 139-45.

[4] S. Aaron, "Climate change adaptation and conflict in Nigeria" U.S Institute of peace Special Report 274, June 2011

[5] L. Osuji. (2002). Some environmental hazards of oil pollution in Niger Delta, Nigeria. African J. Interdisc. Stud. 3 (1). Pp. 11-17.

[6] A. A. Adewumi, O. R. Agunbiade, O. O. Longe, Fadiya, \& I. K. Adewumi, (2018). Climate Change and the Niger Delta Region. Advances in Social Sciences Research Journal. 5(9). Pp. 176-185.

[7] C. U. Oyegun, O. Lawal, \& M. Ogoro. (2016). Vulnerability of coastal communities in the Niger Delta region to sea level rise. Journal of Research in Environmental and Earth Science. 2(8). pp: 01-08.

[8] S.O. Eze \& E.E. Osahon. (2018). Indigenous mitigation and adaptation to climate change among small holders farmers in arochukwu area of Abia State, Nigeria. Asian J agric extension econ social. 6. pp.45-55.

[9] K. K. Aaron. (2005). Perspective: big oil, rural poverty, and environmental degradation in the Niger Delta region of Nigeria Journal of agricultural safety and health. 11(2). pp 127-134.

[10] T. Eyenghe. B. Ibama \& C. Wocha. (2015). Climate change, disaster risk management and the urban poor in Port Harcourt metropolis. International journal of scientific \& technology research. (4) 5.

[11] E.C. Merem, Y. Twumasi, J. Wesley, M. Alsarari1, S. Fageir, M. Crisler, C. Romorno, D. Olagbegi, A. Hines, G.S. Ochai, E. Nwagboso, S. Leggett, D. Foster, V. Purry \& J.Washington. (2019). Regional assessment of climate change hazards in Southern Nigeria with GIS Journal of safety engineering. 8(1). Pp. 9-27.

[12] K. Shehu, I.N. Auwal \& A.A. Dahuwa. (2018). A Review of climate change: Its impacts and governance for enhancing Nigeria's environmental resources. Dutse Journal of Pure and Applied Sciences (DUJOPAS). 4(2).

[13] A. Abdulkadir, L.A. Maryam \& T.I. Muhammad. (2017). Climate change and its implications on human existence in NIGERIA: A review. Bayero Journal of Pure and Applied Sciences. 10(2). Pp.152158.

[14] Intergovernmental Panel on Climate Change (IPCC). Climate Change 2007 - Synthesis Report. 2007.

[15] C.T. Emejuru \& M.O. Izzi. (2015). Climate change and the law: cushioning the effects of climate change- in Niger Delta. Global Journal of Human-social Science: Geography, Geo-sciences, Environmental science \& Disaster management. 15(1). Pp. 1.

[16] UNDP. Niger Delta Human Development report. 2006. [Online]. Available:

https://www.google.com/url?sa=t\&source=web\&rct=j\&url=http://hdr.u ndp.org/en/content/human-development-report\&ved=2ahUKEwi_2c 9mvzrAhVIR0EAHTidAjIQFjAAegQIAxAB\&usg=AOvVaw3wMtu0 A7j-GkWz66U-qG09.

[17] Niger Delta Regional Development Master-plan (NDRDMP). Niger Delta regional master plan. Facilitated by the Niger Delta Development Commission (NDDC) in partnership with the nine states' governments, LGAs, Oil Companies, Civil Society Organizations and Communities in the Niger Delta. 2006.

[18] A. A. Kadafa. (2012). Oil exploration and spillage in the Niger Delta of Nigeria. Civ. Environ. Res. 2. Pp. 38-51.

[19] Z. Nenibarini, S. Kabari T.O. \& Adaugo (2017). Remediation of contaminated lands in the Niger Delta, Nigeria: Prospects and challenges. Science of the Total Environment. [Online]. Available: https://www.google.com/url?sa=t\&source=web\&rct=j\&url=https://ww w.researchgate.net/publication/313773004_Remediation_of_contamina ted_lands_in_the_Niger_Delta_Nigeria_Prospects_and_challenges\&ve $\mathrm{d}=$ 2ahUKEwjXm9bL38nrAhUwRxUIHTcOBnAQFjAAegQIBhAC\&u sg=AOvVaw3jEwnp-LBxL_JkHu6cjOmV.

[20] NDDC. Niger Delta Development Master Plan. 2006. (Unpublished).

[21] E.I. Aniefiok, J.I. Udo, U.I. Margaret \& W.P. Sunday. (2013). Petroleum exploration and production: past and present environmental Issues in the Nigeria's Niger Delta. American Journal of Environmental Protection. 1(4). Pp. 78-90.

[22] S. Pegg \& N. Zabbey. (2013). Oil and water: the Bodo spills and the destruction of traditional livelihood structures in the Niger Delta Commun. Dev. J. 48. Pp. 391-405. 
[23] O.J. Kamalu \& C.C. Wokocha. (2011). Land resource inventory and ecological vulnerability: Assessment of Onne area in Rivers State, Nigeria. Research Journal of Environmental and Earth Sciences. 3(5). Pp. 438-447.

[24] I.O. Ndubusi \& L.O. Asia (2007) Environmental pollution in oil producing area of Niger Delta Basin, Nigeria: Empirical assessment of trend and people perception. Environmental Research Journal. 4. Pp $18-28$.

[25] R. Aichele \& G. Felbermayr. (2012). Kyoto and the carbon footprint of nations. J. Environmental Economics and Management. Pp. 63, 336354

[26] S. L. Tamara, R.V. Juliette \& N. Frank (2016). Addressing climate change through education. Oxford research encyclopedia of environmental science. 40

[27] UNFCCC "Impacts, vulnerability and adaptation to climate change in Africa" Presented at African Workshop on Adaptation Implementation of Decision 1/CP.10. Accra, Ghana. September 21 - 23, 2006.

[28] T. S. Ledley, A. Gold, F. Niepold \& M. McCaffrey. (2014). Moving toward collective impact in climate change literacy: The climate literacy and energy awareness network (CLEAN). Journal of Geoscience Education. 62(3). Pp. 307-318.

[29] T.M. Lee, E.M. Markowitz, P.D. Howe, C.Y. Ko \& A.A. Leiserowitz. (2015). Predictors of public climate change awareness and risk perception around the world. Nature Climate Change. 5(11). Pp. 1014 1020.

[30] C. Lesk, P. Rowhani \& N. Ramankutty. (2016). Influence of extreme weather disasters on global crop production. Nature. 529(7584). Pp 84-87.

[31] U. Etiosa. (2009). The changing climate and the Niger Delta. Community Research and Development Centre (CREDC), Nigeria [Online]. Available : www.climatefrontlines.org) PDFWeb result Climate Change in the Niger Delta - Climate Frontlines.

[32] C. N. Thaddeus, L.E. Chukwudumebi, A.C. Nnaemeka \& C.A Victoria. (2011). Climate change awareness and adaptation in the Niger Delta Region of Nigeria. African Technology Policy Studies Network. 57.

[33] L. Amadi \& C.U. Mac Ogoni. (2015). Climate change, environmenta security, and displacement in Nigeria: Experience from the Niger Delta flood disaster 2012. African Journal of Environmental Science and Technology. 9(1). Pp. 53-64.

[34] O. Odafivwotu, (2015). Public Perception of Climate Change in Yenagoa, Bayelsa State, Nigeria. Hindawi Publishing Corporation Geography Journal. [Online]. 19. Available: https://www.google.com/url?sa=t\&source=web\&rct=j\&url=https://ww w.hindawi.com/journals/geography/2015/208154/\&ved=2ahUKEwinw Jf_48nrAhXirnEKHaGABIIQFjAAegQIAhAB\&usg=AOvVaw23jZiq 3BTjqWOWQJpTrYCG.

[35] H.U. Agbebaku. (2015). Environmental challenges and climate change: Nigeria experience. Journal of Research in Environmental and Earth Science. 2(4). Pp.01-12.

[36] National Population Commission (NPC), (2006). [Online] Available : https://www.google.com/url?sa=t\&source=web\&rct=j\&url =https://www.scirp.org/(S(lz5mqp453edsnp55rrgjct55))/reference/Refe rencesPapers.aspx\%3FReferenceID\%3D1817244\&ved=2ahUKEwiWi qKX5snrAhUQVRUIHckSAHkQFjABegQIAhAB\&usg=AOvVaw0w 7jw4WEZKHPio0Y4K7E2e.

[37] E. Uyigue \& M. Agho (2007). Coping with Climate Change and Environmental Degradation in the Niger Delta of Southern Nigeria, Community Research and Development Centre (CREDC) Nigeria.

[38] Gideon, E.D. O. (2011). Poverty and environmental quality in the Niger Delta region: dependence on biomass fuels as the source of household energy. CEPED monograph series. Available : https://www.africaportal.org> pover. Poverty and Environmental Quality in the Niger Delta Region.

[39] O. Akinyemi, A. Ogundipe and A.P. Adeyemi. (2014). Energy supply and climate change in Nigeria. Journal of Environment and Earth Science. 4(14).

[40] A. Ayansina. (2012). Evaluating environmental change impacts on ecological services in the Niger Delta of Nigeria. Ife Research Publications in Geography. 11(1).

K. J. Andrew, F. Shirley, H. Klaus, L. Jia, M.Tom, R. Torben, B.S. Juliet, S. William, Y. Richard \& Z. Ariela. (2018). Social Science Perspectives on drivers of and Responses to Global Climate Change. WIREs Clim Change.

[41] I. T. Oramah. (2006). The effects of population growth in Nigeria. Journal of Applied Science. 6(6). Pp. 1332-1337.

[42] United Nations Development Programme (UNDP). Niger Delta Human Development Report. 2006.
[43] G.E.D Omuta (1988). The quality of urban life and the perception of livability: A case study of neighborhoods in Benin City, Nigeria. Social Indicators Research. 20. pp. 417-440.

[44] I.D. Choji. (2005). The Impact of Government Policies on Fuel Prices on the Environment. International Journal of Business and Common Markets Studies. 3(2). pp. 94-100.

[45] E. Hetzler, "The interconnection of environment and poverty: Prospects for sustainable development' Undergraduate honors Theses. 293. (2012)

[46] U. Onuche. (2010). Impact of poverty on the sustainability of forests in Nigeria: Implications for Sustainable Forests and Reduction Of Global Warming. Journal of Sustainable Development in Africa. 12(6). Pp 208-215.

[47] M. Watts. (2007). Petro-insurgency or criminal syndicate? Conflict \& violence in the Niger Delta. Rev. Afr. Polit. Econ. 34. Pp. 637-660.

[48] N. Umukoro. (2012). Governance and environmental inequality in Nigeria: implications for conflict management strategies in the Niger Delta. Int. J. Environ. Stud. 69. Pp. 913-920.

[49] D. Okali, \& E. O. Eleri (2004). Climate Change and Nigeria: A guide for Policy Makers. The publication of the Nigerian Environmental Study Action Team (NEST).

[50] Environmental Rights Action (ERA) (2005). Gas flaring in Nigeria: Human rights, environmental and economic monstrosity.

[51] Bayelsa State Ministry of Environment (2011). Climate change policy manual. (Unpublished).

[52] C.U. Oyegun, O. Lawal \& M. Ogoro. (2016). Vulnerability of coastal communities in the Niger Delta region to sea level rise. Journal of Research in Environmental and Earth Science. 2(8). Pp. 01-08.

[53] E. Uyigue \& M. Agho. (2007). Coping with Climate Change and Environmental Degradation in the Niger Delta of Southern Nigeria Community Research and Development Centre (CREDC) Nigeria.

[54] World Bank (1995). Defining an environmental development strategy for the Niger Delta.1, 14266, 1-149.

[55] H.M. Pereira, L.M. Navarro \& I.S. Martins. (2012). Global biodiversity change: the bad, the good, and the unknown. Ann. Rev. Environ. Res. 37. Pp. 25-50

[56] Godfrey, C., A. Nioking, A., Edem, A., Eniang, L. L., and Fabio, P. (2015). Are mammal communities occurring at a regional scale reliably represented in "hub" bush meat markets? A case study with Bayelsa State (Niger Delta, Nigeria).

[57] W. S. Dejene (2018). Impact of climate change on biodiversity and associated key ecosystem services in Africa: A systematic review. Ecosystem health and sustainability, 4(9), 225-239.

[58] F.M. Angelici, I. Grimod \& E. Politano (1999). Mammals of the eastern Niger Delta (Rivers and Bayelsa States, Nigeria): An environment affected by a gas-pipeline. Folia Zool. 48: 249-264.

[59] A. Onwuemele (2015). Livelihood responses to climate change in the Niger-Delta: Implications for food security in Nigeria. Int. J. of Dev. and Management Rev. 10(1). Pp. 1-11.

[60] E.I. Elanwo \& F.U. Ochege. Environment, resources and sustainability in the Niger Delta region, Nigeria. 2018. Ch. 5. (Unpublished Book).

[61] A. O. Adeniran \& H. Oyemade (2016). Inventory analysis of solid waste management in Ikorodu community. Civil and Environmental Research. 8(9)

[62] L.C. Gilbert, M.A. Nwachukwu \& A.P. Uzoije (2018). A Review of petroleum waste management and environmental quality status of Niger Delta. AdvEnvi Was Mana Rec. 1(1). Pp. 2-8.

[63] L.C. Gilbert, M.A. Nwachukwu and A.P. Uzoije (2018). A Review of Petroleum Waste Management and Environmental Quality Status of Niger Delta. Adv Envi Was Mana Rec. 1(1). P.8

[64] I. O. G. Owoeye \& O. H. Okojie (2013). Environmental audit of refuse dump site in the Niger Delta region of Nigeria. Journal of public health and epidemiology. 5(2), pp. 59-65.

[65] C.C. Ike, C.C. Ezeibe, S.C. Anijiofor \& N.N. Nik Daud (2018). Solid waste management in Nigeria: problems, prospects, and policies. Journal of solid waste technology and management. 44 (2).

[66] United Nations Environmental Programme (UNEP). Nigeria Launches $\$ 1$ Billion Ogoniland Clean-up and Restoration Programme -UNEP. 2016

[67] United Nations Environmental Programme (UNEP). Environmenta Assessment of Ogoniland. UNEP, Switzerland. (2011)

[68] N. Zabbey, S. Kabari, and T. O. Adaugo (2017). Remediation of contaminated lands in the Niger Delta, Nigeria: Prospects and challenges. Sci. Total Environ. 21. Pp. 14

[69] ]. A.W. Butu, B.R. Ageda \& A.A. Bichi (2013). Environmental Impacts of roadside Disposal of Municipal Solid Wastes in Karu, Nasarawa State, Nigeria. International journal of environment and pollution research. 1 (1). Pp. 1-9. 
[70] I.K. Bello \& O.S. Arowosegbe (2014). Factors affecting land-use change on property values in Nigeria. Journal of research in economics and international finance (JREIF). 3(4). Pp. $79-82$.

[71] C. Emuedo and M. Abam (2015). Oil, land alienation and impoverishment in the Niger Delta, Nigeria. European journal of research in social sciences. 3(2). Pp. 8-23.

[72] K.A. Ayuba (2012). Environmental impacts of oil exploration and exploitation in the Niger Delta of Nigeria. Global journal of science frontier research environment and earth sciences. 12(3), 18-28.

[73] Niger Delta Environmental Survey (NDES). Environmental and Socioeconomic Characteristics. (1997). 1(1).

[74] M. Saheed, H.A. Oludare \& C.E. Evidence (2018). Land use/land cover change in petroleum-producing regions of Nigeria. The Political Ecology of Oil and Gas Activities in the Nigerian Aquatic Ecosystem, 33(8).

[75] C.N. Stephen (2011). Climate change and energy implications of gas flaring for Nigeria. International Journal of Low-Carbon Technologies. 6. Pp. 193-199.

[76] S.F. Iwejingi (2013). Socio-economic problems of oil exploration and exploitation in Nigeria's Niger Delta. Journal of energy technologies and policy. 3(1). Pp. 76-81.

[77] C. Clifford \& S. David (2017). Air pollution due to gas flaring in the Niger Delta: A review of current state of knowledge. Greenpeace Research Laboratories Technical Report (Review).

[78] E.E. Ito \& I.L. Ugbome (2017). Impact of gas flaring on biodiversity in Niger Delta, Nigeria. Nigerian journal of science and environment. 15 (1).

[79] S. Pegg and N. Zabby (2013). Oil and water: the Bodo spills and the destruction of traditional livelihood structures in the Niger Delta. Commun.Dev. J. 48. Pp. 391-405.

[80] A. O. Christopher \& A. F. Michael (2017). Gas flaring in Niger Delta Region of Nigeria: Cost, ecology and human health implications. Environmental management and sustainable development. 6(2)

[81] I. S. Enetimi and C.I. Sylvester (2017). A Review of impacts of gas flaring on vegetation and water resources in the Niger Delta region of Nigeria. International Journal of Economy, Energy and Environment. 2 (4). Pp. 48-55

[82] I.J. Ekpoh and A.E. Obia (2010). The role of gas flaring in the rapid corrosion of zinc roofs in the Niger Delta Region of Nigeria. Environmentalist. 30. Pp. 347-352.

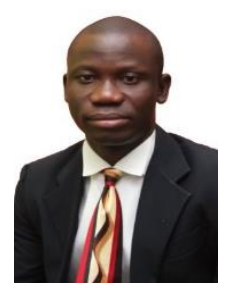

Mr. Authority is a $\mathrm{PhD}$ Student with University of Port Harcourt, Department of Geography and Environmental Management, Rivers State, Nigeria. Born in October 14th 1988 in Agbura town in Yenagoa Local Government Area, Bayelsa State, Nigeria. Hold B.Sc (Hons.) Biotechnology from UCSI University, Kuala Lumpur Malaysia in 2011 and M.Sc Environmental Management from University Putra Malaysia (UPM) at Selangor, Kuala

Lumpur, Malaysia 2013.

$\mathrm{He}$ is a former Lecturer with Institute of Criminology and Penology, Nigeria, Bayelsa State branch in 2015 where he taught Environmental Security Studies. Additionally, he has over ten years working experience with Civil Society Organizations and presently a Lecturer with Niger Delta University, Department of Environmental Management at Faculty of Environmental Sciences, Wilberforce Island, Bayelsa State. His research interest include climate change policy and food security in the Niger Delta region, balancing the relationship between biodiversity conservation and economic development in the Niger Delta, evaluation and projection of long term environmental, health and economic implications of water pollution, gas flaring and oil spills in Niger Delta region. 